\title{
Cryptococcal Meningitis of the HIV-Infected Person in Lomé: About 102 Cases over 10 Years
}

\author{
Ihou Majesté Wateba ${ }^{1}$, Abago Balaka², Alain Lidaw Bawe ${ }^{1}$, Awereou Kotosso ${ }^{1}$ \\ ${ }^{1}$ Tropical and Infectious Diseases Service of CHU SO, Lome, Togo \\ ${ }^{2}$ Internal Medicine Service of CHU SO, Lome, Togo \\ Email: majeste7@yahoo.fr
}

How to cite this paper: Wateba, I.M., Balaka, A., Bawe, A.L. and Kotosso, A. (2017) Cryptococcal Meningitis of the HIV-Infected Person in Lomé: About 102 Cases over 10 Years. World Journal of AIDS, 7, 217-222. https://doi.org/10.4236/wja.2017.73017

Received: May 22, 2017

Accepted: September 16, 2017

Published: September 19, 2017

Copyright (C) 2017 by authors and Scientific Research Publishing Inc. This work is licensed under the Creative Commons Attribution International License (CC BY 4.0).

http://creativecommons.org/licenses/by/4.0/

\section{c) (i) Open Access}

\begin{abstract}
Objective: To describe the clinical, epidemiological and evolutionary aspects of cryptococcal meningitis. Methods: This was a retrospective descriptive study on all HIV-infected patients who had been hospitalized for cryptococcal meningitis between 2006 and 2016 in the principal structures for the care of HIV infected person in Lomé. The diagnosis of meningitis was clinical and confirmed by the presence of cryptococci on Chinese ink or the detection of CSFsoluble antigens. All patients have made the $\mathrm{CD} 4$ rate assay and received an antifungal treatment based on fluconazole or Amphotericin B, followed later by antiretroviral triple therapy. Results: A total of 102 patients infected with cryptococcal meningitis ( 62 men for 40 women) were found. The sex ratio was 1.55. The median age was 34 years with extremes of 15 to 49 years. Clinically, headache was the symptomatic symptom in $100 \%$ of cases, prone to long runs and weight loss respectively in the proportions of $45 \%$ and $65 \%$. The mean CD4 cell count was $65 \pm 22$ cells per $\mathrm{mm}^{3}$. The duration of hospital stay was short (less than 7 days) for the deceased. A total of 62 patients were able to receive treatment, 40 of them with fluconazole and 22 with Amphotericin B. The mortality was very high (65\%), 25\% were lost to follow-up, and $9.5 \%$ still in live 3 months after admission to the hospital. Conclusion: Cryptococcal meningitis has a very reserved prognosis. It is to be feared in cases of severe immunosuppression, hence the early detection of HIV for optimal management is important.
\end{abstract}

\section{Keywords}

Cryptococcal Meningitis, HIV, Lomé

\section{Introduction}

Cryptococcal meningitis is a frequent mycotic meningitis in HIV-infected pa- 
tients with CD4 rate levels $<100$ cells $/ \mathrm{mm}^{3}$ [1] [2] [3]. It is the most lethal opportunistic disease in HIV-infected patients [4]. In Togo, it is often diagnosed but hospital and/or population-based epidemiological data are not available to assess the magnitude of the problem. It is therefore with the aim of elucidating the phenomenon that we have carried out this study in order to describe the epidemiological, diagnostic, therapeutic and evolutionary aspects.

\section{Method}

It was a retrospective and descriptive study which was carried out on files of patients hospitalized in the public structures of HIV treatment in Lomé between 2006 and 2016. The diagnosis of cryptococcal meningitis was based on the presence of cryptococcal yeasts in the cephalo-spinal fluid (CSF) of patients suffering of headache and chronic fever in HIV infection status. All patients had done a CD4 rate and have received either orally and/or parenterally fluconazole antifungal therapy at a dose of 800 to $1200 \mathrm{mg}$ per day, or Amphotericin B to the dose of $0.7 \mathrm{mg} / \mathrm{kg} /$ day, followed later by antiretroviral antiretroviral therapy.

The demographic data, the clinical course under treatment, were the parameters studied.

\section{Results}

Cryptococcal meningitis accounted for 1.5\% (102/8025) of all AIDS consultations over 10 years. The male sex was in the majority with a sex ratio of 1.55 . In $99 \%$ of cases, patients were infected with HIV 1. The reasons for consultation were dominated by headache in all patients and a major immunosuppression was observed in almost all cases. Only $7.8 \%$ of patients had viral load with a viraemia greater than $6 \mathrm{log} / \mathrm{ml}$ (Table 1).

Therapeutically, $83 \%$ of patients were under ARV, with $52 \%$ and $36 \%$, respectively, in the first line therapy with tenofovir lamivudine and efavirenz and secondarily with tenofovir lamivudine and lopinavir/ritonavir. A total of $13 \%$ of

Table 1. General characteristics of the population.

\begin{tabular}{cc}
\hline Effectif/Number & Proportion \\
\hline Epidemiological data & - \\
Median age (extremes) $34(15-49)$ & - \\
Sex H/F 62/40 & - \\
Type of HIV (1/2) 101/1 & \\
Clinical data & $100 \%$ \\
Headaches 102 & $45 \%$ \\
Fiver 46 & $65 \%$ \\
Cachexia 66 & \\
Biological data & - \\
Mean CD4 rate \pm standard deviation $65 \pm 22$ & $08 / 102$ \\
Mean viral load 6 Log &
\end{tabular}


patients had given up ARVs and 4\% were naïve to ARV treatment. Within the patients who had abandoned ARV and those ARV-naïve, 11 (11\%) were using either herbal treatments, dietary supplements or prayers (Table 2).

All patients did not receive antifungal treatment. Thus, of the patients who were treated (61\%), $40 \%$ or $64 \%$ received fluconazole injection for 7 days followed by the oral form. Amphotericin B was administered only in $36 \%$ of cases and in $39 \%$ of cases no treatment was given (Table 3 ).

In terms of progression, lethality was very high (65\%) and in $28 \%$ of cases, patients were released from hospital on request. Only $9.5 \%$ of patients who were treated remained alive 3 months after admitted at the hospital. In addition, headache persistence was observed in almost all patients (Table 4).

\section{Discussion}

The $1.5 \%$ frequency represented by cryptococcal meningitis in AIDS consultations shows that this disease is more frequent than we can imagine. Millogo in

Table 2. Former therapeutic status of the patients before admission.

\begin{tabular}{cc}
\hline Effectif & Proportion \\
\hline ARV therapy 85 & $\mathbf{8 3 \%}$ \\
First line 54 & $64 \%$ \\
Second line 31 & $36 \%$ \\
Abandonment of treatment ARV 13 & $13 \%$ \\
Patient naive from ARV 04 & $04 \%$ \\
Other treatment 11 & $11 \%$ \\
Plants 08 & $72 \%$ \\
Dietary supplements 07 & $63 \%$ \\
Payer 04 & $36 \%$ \\
\hline
\end{tabular}

Table 3. Distribution of patients according to the antifungal treatment received.

\begin{tabular}{cc}
\hline Effectif & Proportion \\
\hline Antifungal treatment 62 & $61 \%$ \\
Fluconazole 40 & $64 \%$ \\
Amphotéricine B 22 & $36 \%$ \\
Lake of treatment 40 & $39 \%$ \\
\hline
\end{tabular}

Table 4. Evolutionary characteristics under antifungal treatment.

\begin{tabular}{cc}
\hline Effectif & Proportion \\
\hline Persistence of headache 99 & $97 \%$ \\
Intracranial hypertension syndrome 85 & $83 \%$ \\
Death in the first 7 days 55/65 & $65 \%$ \\
Prolonged survival after 3 months 10 & $9.5 \%$ \\
Exit against medical agreement 29 & $28 \%$ \\
\hline
\end{tabular}


Burkina Faso reports the same frequency [5]. Clinically, diagnostic confusion is possible with other febrile tropical diseases such as malaria, which have common fever and headache. Moreover, the discovery of cryptococcus in the context of meningitis calls for the practice of the lumbar puncture which can prove difficult to achieve.

The male sex is predominant in our study. This trend was also observed by Bissagnené in Côte d'Ivoire and Ki-Zerbo in Burkina Faso [6] [7]. Clinically, headaches were the major symptom of intracranial hypertension and the most important factor in suspecting neuromeningin cryptococcosis in HIV-infected patients (Table 1).

At the immune level, all patients were in the AIDS phase of HIV with a very high viral load greater than $6 \mathrm{Log} / \mathrm{ml}$. Note that cryptococcosis is an opportunistic disease of AIDS and is seen mainly at the terminal phase of the evolution of HIV characterized by a collapse of immunity and a very high plasma viral load as can be seen in many studies [8] [9]. In Togo, the discovery of an HIV infection is still occurring today with to the discovery of an opportunistic infection. Very often, the first symptoms of immunosuppression, such as recurrent morbid states, are confused with Malaria, and finally the HIV infection diagnosis is delayed after the failure of other therapies.

Therapeutically, the majority of patients were on antiretroviral therapy. However, despite this treatment, there is a strong immunosuppression, indicating either a poor ARV intake or failure of the ARV therapy because of resistance. In Togo, for the whole population of HIV infected patients under ARV, Dagran observes in 2011 a rate of resistance on drugs used in the first line therapy of $24.5 \%$ [10] and a Konou fund in 2015 a resistance rate on protease inhibitors used in the second line therapy of $17 \%$ [11]. It's good to remember that in the years 2007 to 2008 in Togo, There have been many breaks in the supply of ARVs. It was only in 2009 that the situation became normal as a result of the resumption of co-operation with the Global Fund. The role of treatment interruptions in the occurrence of resistance and therapeutic failures is well demonstrated [12].

In addition, cryptococcosis was the discovery circumstance of HIV with 4 patients. This is proof that many people are unaware of their HIV status. This contributes to the spread of the infection in a context dominated by illiteracy. The study also showed that $11 \%$ of patients had other care outside of ARV treatment. This is the taking of nutritional supplements that abound nowadays in markets in Togo. These products, although of dubious origin, cost a lot of money, which contributes to impoverish patients by knowing that HIV already reduces their productive power considerably. Some patients, who numbered 4 in our study, prayer is the refuge, evidenced by the proliferation of places of prayer which often, in disregard of medical prescriptions, encourage patients on ARV to stop treatment for profit of prayer to hope for a divine miraculous healing. As a result, many patients were killed while they were doing well under ARV before their spiritual conversion. 
Anti-fungal treatment was not systematic in all patients. The reasons were the high cost of drugs that were not available to all patients. In Togo, the daily cost of injectable fluconazole (Triflucan ${ }^{\mathrm{R}}$ ) of Pfizer laboratory was US \$20 and that of Amphotericin B when available was US \$ 15. These difficulties are always the cause of the abandonment of treatment obliging the patients to ask to go home against medical advice and prefer practices such as the prayer and the use of the medicinal plants.

In relation to the evolution, lethality was very high. And these deaths occurred within the first week after admission of the patients. The inefficiency of ARV treatment would be the reason. Indeed, from 2008 to 2010, Togo experienced several ruptures in the supply of ARVs. However, it is well known that poor adherence to ARVs is the major cause of ARV resistance and inefficiency [10] [11] [12]. This explains why in our study we find a very high viral load greater than 6 Log in the patients who were able to carry out the PCR. As for the CD4 count, it was collapsed in all patients, whether or not they were on ARV.

However, despite the constraints and inaccessibility of antifungal treatment, approximately $10 \%$ have survived 3 months after starting treatment. But, their future development could not be assessed as the chronic phase of treatment no longer takes place in hospitals, which are reserved only for patients who are bedridden.

\section{Conclusion}

The lethality of cryptococcal meningitis remains very high. In Togo, the problem is worrying marked by the high cost in antifungals that is not within reach of patients. Similarly, the early diagnosis of a therapeutic failure, which causes opportunistic infections like cryptococcosis, must be implemented.

\section{References}

[1] Millogo, A., Ki-Zerbo, G., Andonaba, A.J.B., et al. (2004) La cryptococcose neuroméningée au cours de l'infection par le VIH au Centre hospitalier de Bobo-Dioulasso (Burkina Faso). Bulletin de la Societe de Pathologie Exotique, 97, 119-121

[2] Eholie, S.P., Adou-Brynh, D., Domoua, K., et al. (2000) Méningites lymphocytaires non virales de l'adulte à Abidjan (Côte d'Ivoire). Bulletin De La Societe De Pathologie Exotique, 93, 50-54.

[3] Swinne, D., Taeman, H., Batung Xayano, J., et al. (1994) Contribution à l'étude de l'écologie de cryptococus neoformans en Afrique Centrale. Medecine Tropicale, 54, 53-55.

[4] Lucas, S.B., Hounnou, A., Peacok, C., et al. (1993) The Mortality and Pathology of HIV Infection in West Africa city. AIDS, 7, 1569-1579.

https://doi.org/10.1097/00002030-199312000-00005

[5] Millogo, A., Ki-zerbo, G.-A., Sawadogo, A., et al. (2004) Manifestations neurologiques associées à l'infection par le VIH au centre hospitalier de Bobo Diolasso (Burkina Faso). Bulletin De La Societe De Pathologie Exotique, 97, 119-121.

[6] Bissangnéné, E., Ouhon, J., Kra, O., et al. (1994) La cryptococcose neuro méningée à Abidjan. Médecine et Maladies Infectieuses, 24, 580-585. 
https://doi.org/10.1016/S0399-077X(05)81272-7

[7] Ki-zerbo, G., Sawadogo, A., Millogo, A., et al. (1996) La cryptococcose neuro méningée au cours du SIDA: Étude préliminaire à l'hôpital de Bobo Diolasso (Burkina Faso). Médecine d'Afrique Noire, 44, 13-18.

[8] Mbuagbaw, J.N., Biholong, N.P. and Njamnshi, A.K. (2006) Cryptococal Meningitis and HIV in the Internal Medicine Service at the Yaoundé University Teaching Hospital, Cameroon. African Journal of Neurological Sciences, 25, 13-20.

[9] Assogba, K. and Wateba, I.M. (2015) Neuromeningeal Cryptococcosis in Sub-Saharan Africa: Killer Disease with Spares Data. Journal of Neurosciences in Rural Practice, 6, 221-224. https://doi.org/10.4103/0976-3147.153231

[10] Dagnra, A.Y., Vidal, N., Mensah, A., Patassi, A. and Aho, K. (2011) High Prevalence of HIV-1 Drug Resistance among Patients on First-Line Antiretroviral Treatment in Lomé, Togo. Journal of the International AIDS Society, 14, 30. https://doi.org/10.1186/1758-2652-14-30

[11] Konou, A.A., Danran, Y.A., Vidal, N., Adam, Z., et al. (2015) Alarming Rate of Virological Failure and Drug Resistance in Patients on Long Term Antiretroviral Treatment in Routine HIV Clinics in Togo. AIDS, 29, 2527-2530.

https://doi.org/10.1097/QAD.0000000000000906

[12] Aghokeng, A.F., Monleau, M., Eymard-Duvernay, S., Dagnra, A., Kania, D., et al. (2014) Extraordinary Heterogeneity of Virological Outcomes in Patients Receiving Highly Antiretroviral Therapy and Monitored With the World Health Organization Public Health Approach in Sub-Saharan Africa and Southeast Asia. Clinical Infectious Diseases, 58, 99-109. https://doi.org/10.1093/cid/cit627

\section{Submit or recommend next manuscript to SCIRP and we will provide best} service for you:

Accepting pre-submission inquiries through Email, Facebook, LinkedIn, Twitter, etc. A wide selection of journals (inclusive of 9 subjects, more than 200 journals)

Providing 24-hour high-quality service

User-friendly online submission system

Fair and swift peer-review system

Efficient typesetting and proofreading procedure

Display of the result of downloads and visits, as well as the number of cited articles

Maximum dissemination of your research work

Submit your manuscript at: http://papersubmission.scirp.org/

Or contact wja@scirp.org 